\title{
SEJARAH PEMBENTUKAN DAN PEMBARUAN HUKUM KELUARGA ISLAM DI NUSANTARA
}

\author{
Ahmad Rajafi
}

IAIN Manado

\begin{abstract}
Abstrak
Sejarah pembentukan dan pembaruan hukum keluarga Islam di Indonesia tidak pernah bisa terlepas dari dialektika evolusi budaya hukum yang terjadi dari waktu ke waktu. Model utama dari penggerak evlousi tersebut ada pada semangat penyebar Islam yang menerapkan teori inkulturasi namun tereduksi dengan semangat akulturasi yang melahirkan arabisasi Islam. Pada fase akulturasi inilah terjadi stagnasi pembaruan hukum keluarga dan bahkan mazhab asy-syafi'iyyah menjadi pegangan utama dalam menerapkan hukum keluarga. Semangat pembaruan baru muncul kembali di era 50-an dengan melahirkan istilah Fiqh Indonesia dan Kewarisan Bilateral. Semangat ini berlanjut di era reformasi dengan lahirnya CLD-KHI sebagai pembanding KHI dan diharapkan menjadi UU Perkawinan yang baru. Namun gerakan tersebut kembali stagnan karena begitu mengakarnya hasil pembentukan hukum keluarga Islam berbasis akulturasi di Nusantara.
\end{abstract}

Kata Kunci: Sejarah pembentukan, pembaruan, hukum keluarga Islam, nusantara

The History of the Establishment and Improvement of the Islamic Family Law in the Archipelago of Indonesia

The history of the establishment and improvement of the Islamic family law in Indonesia can never be separated from law cultural evolution discourse that occurs from time after time. The first model of the evolution motor laid on the spirit of the Islam spreaders who applied inculturation brought forth the Arabization of Islam. In the acculturation phase, the improvement of family law is paused and make the mazhab asy-syafiiyyah as the main base in family law enforcement. The call for improvement reemerged in the 1950s by introducing Indonesian Fiqh and bilateral inheritance. The course continued to the reform era noted by the introduction of CLD-KHI as a counter to KHI and expected to the new marriage regulation. However, the movement was halted again since acculturation has rooted in the development of Islamic family law.

Keywords: the history of establishment, improvement, Islamic family law. 


\section{A. Pendahuluan}

Islam sebagai agama memberi arahan berpikir bagi umatnya untuk mengembangkan ajarannya hingga pada ranah taqniniyyah (hukum perundang-undangan) yang dapat dimplementasikan secara utuh bagi seluruh pemeluknya. Konsep implementasi utuh atas ajaran tersebut digambarkan di dalam alQuran dengan istilah ketaatan yang ditujukan kepada Allah swt, Nabi Muhammad saw sebagai utusan-Nya, dan ulil amri. Allah swt berfirman:

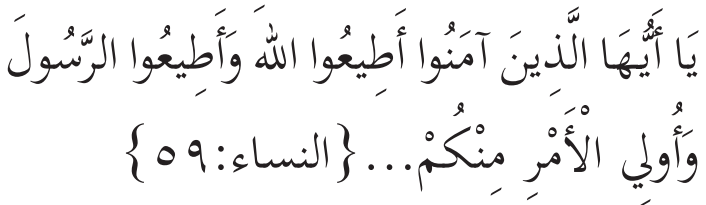

Artinya : "Hai orang-orang yang beriman, taatilah Allah dan taatilah Rasul (Nya), dan ulil amri di antara kamu..." (QS. an-Nisa' : 59)

Terdapat beragam penafsiran atas makna ulil amri ( أولى الأمر) dari beberapa ahli tafsir di dunia. Ath-Thabari secara runtut menjelaskan beragam makna dari ulil amri tersebut, yakni: al-umara' (pemerintah); ahl al-'ilmi wa al-fiqhi (ahli agama); ashhab Muhammad saw (para sahabat Nabi saw); atau Abu Bakar dan Umar bin Khaththab. ${ }^{1}$ Meskipun demikian, secara pribadi beliau memilih makna pertama, yaitu umara' karena adanya riwayat yang shahih dari Rasululullah saw untuk patuh kepada umara' selama taat kepada Allah dan membawa kemaslahatan kepada umat. ${ }^{2}$ Adapun M. Quraish Shihab memaknai ulil amri sebagai orang-orang yang berwewenang mengurus urusan kaum muslim, dan diandalkan dalam menangani

Abu Ja'far Muhammad ibn Jarir ath-Thabari, Jami' al-Bayan 'an Ta'wil al-Qur'an, (Beirut: Dar al-Fikr, 1988), Juz 8, h. 496-501 Ibid, h. 502 persoalan-persoalan kemasyarakatan. ${ }^{3}$ Secara implisit, pendapat Quraish Shihab sejalan dengan pendapat ar-Razi yang menjelaskan bahwa ulil amri adalah ahl al-halli wa al'aqdi dari umat ${ }^{4}$. Pendapat ar-Razi tersebut dipertajam oleh Abduh dengan menyebutkan kualifikasinya, yakni umara' (pemerintah) dan hukama' (penguasa), ulama, para panglima, dan semua pemimpin masyarakat. ${ }^{5}$ Pada konteks ini, maka pendapat Abduh responsif dengan sosio-kultur masyarakat Nusantara yang majemuk.

Atas dasar kualifikasi tersebut, maka segala regulasi yang dikeluarkan untuk kepentingan masyarakat umum tentu harus dilahirkan secara kolektif dan bukan personal agar sisi responsivitas hukum menjadi terwujud. Salah satu regulasi yang urgen dalam pandangan umum adalah tentang hukum keluarga karena semua dasar sosiologis berasal dari keluarga. Secara historis, berbagai regulasi hukum keluarga di Nusantara dijabarkan secara personal oleh para ulama di Nusantara atas dasar pembacaan dan pembelajaran mereka dari guru-guru mereka. Pada sisi inilah maka progresivitas hukum menjadi terhambat karena penjelasan dari para ulama dianggap sakral dan tidak boleh dipertentangkan apalagi dievaluasi dan direvisi.

Tidak bisa dipungkiri bahwa era stagnasi (jumud) ilmu pernah terjadi pada masa lalu akibat sakralisasi masyarakat terhadap ulama, baik pribadinya maupun pemikirannya. Inilah yang saat ini dirasakan oleh umat Islam di Indonesia yang mulai merasa nyaman dengan Kompilasi Hukum

M. Quraish Shihab, Tafsir Al-Misbah, (Jakarta: Lentera Hati, 2000), Vol. 2, h. 460

Fakhr ad-Din ar-Razi, Mafatih al-Ghaib, (Beirut: Dar al-Fikr, 1995), Jil. 10, h. 113

As-Sayyid Muhammad Rasyid Ridha, Tafsir Al-Qur'an al-Hakim: Tafsir al-Manar, (Beirut: Dar al-Fikr, 1973), Jil. 5, h. 147 
Islam (KHI) dan berimplikasi pada sakralitas baru sehingga KHI seolah-olah tidak lagi dapat dievaluasi apalagi direvisi. Padahal, sejarah banyak menggambarkan tentang evolusi hukum termasuk dalam hal hukum keluarga. Oleh karena itu, melalui pendekatan historis, paper ini akan menggambarkan secara holistik sejarah evolusi hukum keluarga Islam di Nusantara.

\section{B. Budaya Hukum Keluarga di Nusantara}

Kajian tentang budaya hukum keluarga mencakup keadaan keluarga di dalam masyarakat, sistem dan susunannya yang mengandung budaya hukum. Hilman memberi batasan berupa tanggapan yang bersifat penerimaan atau penolakan terhadap suatu peristiwa hukum, yang menunjukkan sikap perilaku manusia terhadap masalah hukum dan peristiwa hukum yang terbawa ke dalam masyarakat, ${ }^{6}$ termasuk hukum keluarga Islam di Nusantara.

Khairuddin Nasution dalam paper-nya membuat klasifikasi kekerabatan sebagai basis ideologi keluarga, yakni:

1. Pasti menimbulkan kesatuan-kesatuan kekeluargaan besar, seperti klan, marga dan suku;

2. Garis kekeluargaan dihubungkan lewat garis ayah (laki-laki);

3. Bentuk perkawinan exogami, di mana nikah hanya boleh dengan orang di luar marga/suku/klan, dan dilarang perkawinan antar-suku (indogami). ${ }^{7}$

Pada aspek kekerabatan matrilineal

Hilman Hadikusuma, Antropologi Hukum Indonesia, (Bandung: Alumni, 1986), h. 52

Khoiruddin Nasution, "Arah Pembangunan Hukum Keluarga Islam Indonesia: Pendekatan Integratif dan Interkonektif dalam Membangun Keluarga Sakinah", ASY-SYIR'AH Jurnal Ilmu Syari'ah dan Hukum, Vol. 46, No. 1, Januari-Juni 2012, h. 92 misalnya, penentuan hak dan kewajiban didominasi oleh garis ibu dengan bentuk perkawinannya adalah semanda, di mana setelah terjadinya perkawinan suami melepaskan kewargaan adatnya dan memasuki kewargaan adat istri, sehingga muncul persepsi bahwa kedudukan istri lebih tinggi dari hak dan kedudukan suami. Hilman menjelaskan bahwa pada konteks ini, suami adalah pembantu istri dalam menegakkan rumah tangga dan mempertahankan serta meneruskan keturunan istri, karena istri memiliki kendali yang besar dalam urusan rumah tangga, keluarga dan kerabatnya. Jika istri adalah anak tertua (sebagaimana adat Semende Sumatera Selatan) maka ia bertugas sebagai penunggu harta peninggalan orang tua (tunggu tubang) yang tidak terbagi-bagi, dan suami hanya dapat ikut serta mengurus dan menikmati saja atas harta tersebut tanpa ada hak penguasaan. ${ }^{8}$ Jadi, dalam hal cintamencintai, hormat-menghormati, kesetiaan dan saling memberi bantuan lahir batin antara satu dengan yang lain di kalangan masyarakat matrilineal, lebih dititik beratkan pada kewajiban suami melindungi istri dan anak-anaknya. ${ }^{9}$

Adapun pada aspek kekerabatan parental atau bilateral, tidak ada dominasi kekuasaan hak dan kewajiban antargaris keturunan lakilaki atau perempuan, semua memiliki hak dan kewajiban yang sama baik di hadapan keluarga ataupun masyarakat, dengan bentuk perkawinannya adalah bebas yang tidak mengenal jujur dan semanda, di mana setelah perkawinan suami-istri bebas memilih apakah akan menetap di tempat suami atau di tempat istri, atau membangun sendiri kehidupan baru yang lepas dari pengaruh

Hilman Hadikusuma, Hukum Kekerabatan Adat, (Jakarta: Fajar Agung, 1987), h. 22

Ibid., h. 24 
orang tua masing-masing. ${ }^{10}$

Pola kekerabatan parental atau bilateral di atas merupakan pola dominan yang bergerak di bumi Indonesia, seperti Aceh, Kalimantan, Jawa, dan lain-lain, dan ia merupakan embrio dari participant culture yang mampu menjadi rujukan dalam mewujudkan hukum-hukum baru yang progresif namun tetap responsif. Karena pada klasifikasi ini, setiap individu memiliki hak dan kewajiban yang sama di hadapan hukum, sehingga dapat ikut serta menilai setiap peristiwa hukum, merasa terlibat dalam kehidupan dan pembentukan hukum, baik yang menyangkut kepentingan umum ataupun kepentingan keluarga dan pribadi.

Pola seperti ini menjadi contoh yang nyata tentang budaya hukum keluarga yang dinamis, sehingga masyarakatnya mampu untuk lebih mengekspresikan kehendak dan kemampuan mereka pada pembangunan hukum yang membebaskan, lebih mencerahkan, lebih adil dan lebih manusiawi, karena pembangunan yang berwawasan budaya hukum dikatakan berhasil apabila ia mampu meningkatkan harkat dan martabat manusia, dan bukan semata-mata menghasilkan tercapainya kecukupan dan kelimpahan materiil, melainkan untuk menghadirkan penguatan nilai-nilai fundamental kehidupan manusia itu sendiri. ${ }^{11}$

Fakta ragam kekerabatan di atas menunjukkan bahwa secara historis, budaya hukum di Indonesia telah banyak mengalami evolusi karena telah bersentuhan dengan kebudayaan bangsa-bangsa lain yang lebih maju, seperti India, Persia, Arab, Cina, Eropa, dan lain-lain, termasuk ajaran-ajaran agama

$10 \quad$ Ibid., h. 27

11 Mengenai pembangunan hukum berwawasan budaya, lihat "Prolog: Wawasan Budaya untuk Pembangunan Konsep, Nilai dan Institusi”, dalam Tim Puspar UGM (Peny.)., Wawasan Budaya Untuk Pembangunan: Menoleh Kearifan Lokal, (Yogyakarta: Pilar Politika, 2004), h. xx-xxi mereka melalui socio-politico-religious dari masing-masing pembawanya, dan Indonesia merupakan tempat yang paling sempurna untuk melukiskan pertemuan keragaman agama-agama dunia tersebut, selain dari kondisi kebangsaan, kesukuan dan ras yang sangat plural. Y. van Passen mencatat, bahwa siapa pun yang menulis tentang Indonesia untuk dikenalkan kepada dunia luas, namun tidak menguraikan secara detil aspek agama dalam penelitiannya, maka dapat dikatakan orang tersebut tidak mempunyai banyak pengetahuan tentang objek penelitiannya itu. $^{12}$

\section{Pertemuannya dengan Islam}

Pembentukan budaya hukum keluarga di Indonesia adalah karena adanya kontak dengan budaya asing, yang tentunya juga membawa socio-politico-religious dari masing-masing pembawanya. Perbedaan dari dominasi budaya asing tersebut telah pula menciptakan identitas budaya hukum baru (termasuk Islam) yang berbeda antara satu sama lainnya. Kontak antarbudaya tersebut terjadi melalui dua model, yakni model akulturasi dan inkulturasi. Kedua model ini menjadi motor penggerak utama, karena menurut Ahmad Tholabi, kebudayaan di Indonesia tidak berbentuk satu kesatuan yang sama, tetapi memiliki beberapa bentuk yang jelas-jelas berbeda. Corak yang berbedabeda itu disebabkan oleh kondisi fisik yang menjadi landasan di mana suatu masyarakat itu berbeda. Namun hal itu tidak berarti meniadakan kesatuan dalam kebudayaan, tapi dasar kesatuan kebudayaan Indonesia telah ada sejak zaman pra-Hindu meskipun juga terdapat variasi-variasi lokal. ${ }^{13}$

\footnotetext{
12 Y. van Passen, "Kerjasama Antar Agama dan Prospeknya: Kasus Sulawesi Utara”, Prisma, No. 5, Edisi 1978, h. 18

13 Ahmad Tholabi Kharlie, Hukum Keluarga Indonesia, (Jakarta:
} 
Salah satu penelitian yang telah melakukan klasifikasi atas rumpun sistem hukum adat yang ada di Indonesia adalah van Vollenhoven, dengan membagi persekutuan hukum masyarakat Indonesia menjadi sembilan belas persekutuan yang satu sama lain berbeda, ${ }^{14}$ yakni: (1) Aceh, yang terdiri atas Aceh Besar, Aceh Barat, Singkel, dan Simuelue; (2) Tanah Gayo yang terdiri atas Tapanuli Utara, Tapanuli Selatan dan Nias; (3) Daerah Minangkabau yang dibagi menjadi Minangkabau dan Mentawai; (4) Sematera Selatan, yang terdiri atas Bengkulu, Lampung, Palembang dan Jambi; (5) Darah Melayu; (6) Bangka Belitung; (7) Kalimantan; (8) Minahasa; (9) Gorontalo; (10) Toraja; (11) Ternate; (12) Maluku; (13) Maluku Ambon; (14) Irian; (15) Kepulawan Timor; (16) Bali dan Lombok; (17) Jawa Tengah, Jawa Timur dan Madura; (18) Daerah Kerajaan Solo dan Yogyakarta; (19) Jawa Barat.

Adapun dalam konteks pertemuan budaya hukum keluarga lokal dengan Islam, para pendakwah awal termasuk para wali-wali Islam di seluruh wilayah Indonesia, menerapkan model inkulturasi sebagai rujukan utama Islam dalam melakukan penetrasi dan Islamisasi di awal-awal visitasi mereka ke Indonesia. Akan tetapi model inkulturasi ini dalam perjalanannya kemudian ditinggalkan oleh para penerus pendakwah Islam, karena melihat dan merasakan Islam di Indonesia kini telah terbangun dengan sempurna secara kuantitas namun belum dalam hal kualitas, maka menjadi sangat urgen untuk segera menetapkan bangunan hukum keluarga baku yang mengikat bagi setiap umat Islam

Sinar Grafika, 2013), h. 94-95

14 Lihat Utrecht, Pengantar dalam Hukum Indonesia, (Jakarta: Balai Buku Indonesia, 1953), h. 61; lihat pula Simorangkir dan Woerjono Sastropranoto, Pelajaran Hukum Indonesia, (Jakarta: Gunung Agung, 1957), h. 70
Indonesia melalui kodifikasi fiqh syafi'iyyah ${ }^{15}$ atas perintah raja. ${ }^{16}$ Proses seperti ini dapat diklasifikasi periode makkiyyah dan madaniyyah ${ }^{17}$ model Islam Nusantara.

15 Model fiqh ini sangat menekankan kepada unsur normatif Islam yakni al-Quran, Sunnah, Ijma" dan Qiyas yang disadur dari pemikiran Imam asy-Syafi'i sebagai “Pembela Sunnah” dengan konstruk pemikirannya adalah mengemukakan sintesis atas tesis dan antitesis dari berbagai keunggulan dan kelemahan yang terpapar dalam perdebatan ilmiah yang terjadi antara kelompok ulama Madinah dan Irak. Lihat Abd. Rahman Dahlan, Ushul Fiqh, (Jakarta: Amzah, 2010), h. 27

16 Pada abad ke-13 M, Kerajaan Samudra Pasai di Aceh Utara menganut hukum Islam Madzhab Syafi'i. Kemudian pada abad ke 15 dan 16 M di pantai utara Jawa, terdapat Kerajaan Islam, seperti Kerajaan Demak, Jepara, Tuban, Gresik dan Ngampel. Fungsi memelihara agama ditugaskan kepada penghulu dengan para pegawainya yang bertugas melayani kebutuhan masyarakat dalam bidang peribadatan dan segala urusan yang termasuk dalam hukum keluarga atau perkawinan. Sementara itu, di bagian Timur Indonesia berdiri pula kerajaan-kerajaan Islam seperti Gowa, Ternate, Bima dan lain-lain. Masyarakat Islam di wilayah-wilayah tersebut juga menganut hukum Islam Mazhab Syafi'i. Lihat Hamka, Sejarah Umat Islam Jilid II, (Jakarta: Bulan Bintang, 1976), h. 53; Amrullah Ahmad SF dkk., Dimensi Hukum Islam Dalam Sistem Hukum Nasional, (Jakarta: Gema Insani Press, 1996), h. 70; dan Mawarti Djoned Poesponegoro dkk., Sejarah Nasional Indonesia Jilid III, (Jakarta: Balai Pustaka Departemen Pendidikan dan Kebudayaan, 1984), h. 197

17 Dalam kajian studi al-Quran, materi tentang makkiyyah terkonsentrasi pada perbaikan akidah, pendalaman akar akidah, dan penjagaan atas purifikasi akidah. Sedangkan materi tentang madaniyyah terkonsentrasi pada pembentukan masyarakat Islami, dengan menelurkan ketentuan-ketentuan hukum dan peratuaran baru sehingga tercipta pembangunan umat beserta batasan dalam hubungan sosial mereka. Lihat Manna' alQaththan, Tarikh at-Tasyri' al-Islami, (Kairo: Maktabah Wahbah, t.th.), h. 45-52 


\section{PERIODESASI MAKKIYYAH DAN MADANIYYAH DI INDONESIA}

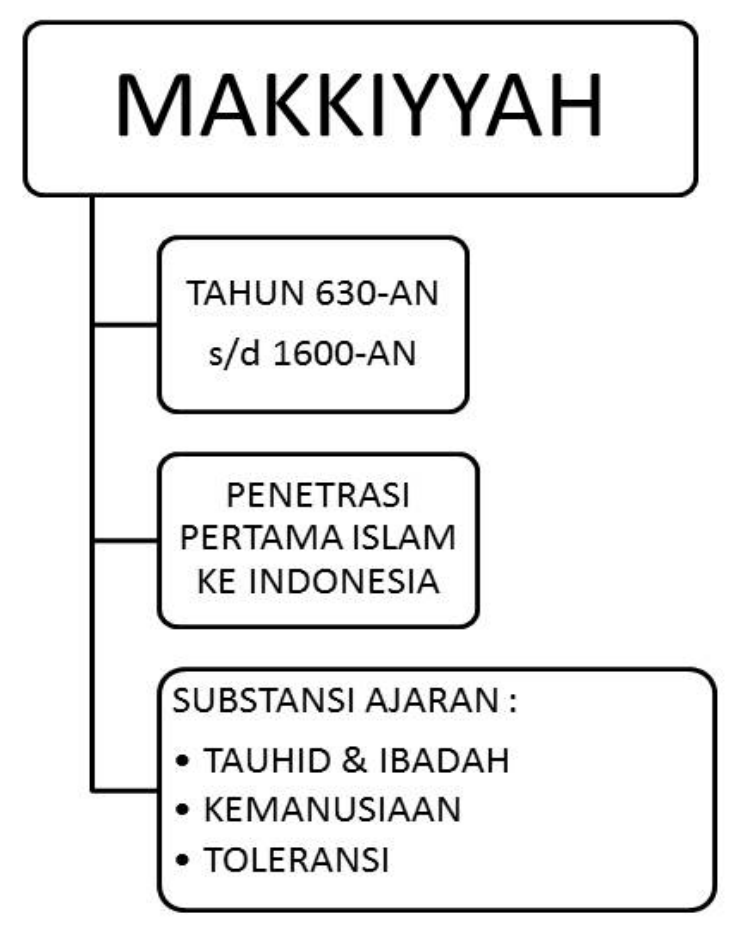

Pada periode makkiyyah yang lahir di tahun 630-an atau abad VII itu, pada dasarnya merupakan masa di mana Hinduisme dan Budhisme telah berurat dan berakar, khususnya di wilayah Sumatera dan Jawa. Bahkan kedua wilayah itu menjadi pangkalan utama perkembangan dan kemunculan rohaniawan kedua agama tersebut, termasuk di dalamnya adalah kerajaan Sriwijaya yang terletak di bagian selatan pulau Sumatera dan kerajaan Mataram, Singasari, dan Majapahit di pulau Jawa. ${ }^{18}$ Namun ternyata Islam mampu menembus dinding besar kedua isme di atas, melalui kontak harmonis antara Islam dan budaya lokal yang akomodatif (inkulturasi) dengan tiga substansi ajaran:

1. Ajaran ketauhidan dengan pendekatan sufistik, di mana Tuhan yang Esa (monoteistik) memiliki kedudukan yang paling

18 Gavin W. Jones, "Agama-agama di Indonesia: Sejarah dan Perkembangannya", Prisma, No. 5, 1978, h. 49

\section{MADANIYYAH}

TAHUN 1600-

AN

PEMBENTUKAN

DAN

KODIFIKASI

HUKUM ISLAM

SUBSTANSI AJARAN

- KODIFIKASI FIQH SYAFI'IYAH

- PELEMBAGAAN ISLAM LEWAT KERAJAAN

tinggi, dan semua makhluk (manusia) yang ada di bawah-Nya memiliki kedudukan yang sama dan sekaligus menjadi khalifah-Nya di muka bumi, dan menghadirkan ajaran ke selanjutnya, yakni;

2. Kemanusiaan, di mana perubahan sosial menjadi semangat utamanya, dari masyarakat yang sebelumnya menganut kasta menjadi saling menghargai atas nama kemanusiaan, dan dari ajaran kedua ini maka muncul ajaran ke selanjutnya, yakni;

3. Toleransi, di mana sikap menghormati atas adanya perbedaan - bahkan dalam masalah keimanan - mampu menarik simpati yang luas dari penduduk lokal Indonesia dan dengan suka rela masuk ke dalam Islam.

Pada periode ini hukum tidak menjadi 
panglima, karena yang diharapkan adalah tersebarnya syiar Islam secara sempurna melalui kecakapan identitas baru tersebut, maka yang dilakukan oleh para penyebar awal Islam adalah dengan masuk ke dalam struktur budaya mereka melalui jalur perkawinan dan kemudian memberikan pemahaman yang utuh tentang nilai-nilai ketauhidan, kemanusiaan, dan toleransi sehingga mereka mampu menerima Islam secara suka rela. Oleh karena itu, demi mendapatkan keutuhan identitas Islam pasca penerimaan massal dari masyarakat lokal atas keberadaan Islam, maka dibutuhkan penguatan identitas tersebut melalui materi yang akan dibahas pada periode kedua.

Periode kedua yang dimaksudkan di atas adalah tentang kontak Islam dengan budaya lokal di Indonesia (madaniyyah) dalam bentuk kodifikasi hukum Islam dan pelembagaan hukum melalui titah raja dengan pendekatan akulturasi. Di sinilah mulai dilakukan klasifikasi pembidangan hukum secara fiqhiyyah dengan genealogi asysyafi'iyyah melalui tema utamanya adalah al'ibadah, al-mu'amalah, al-jinayah, as-siyasah, al-munakahah, dan lain-lain, dengan materi al-'ibadah sebagai materi dominan di dalam kitab-kitab tersebut.

Terkait materi hukum keluarga, kerajaan langsung melakukan pelembagaan hukum melalui penunjukkan qadhi (hakim) yang berasal dari unsur ulama sebagai pengesah perkawinan, plus sebagai penengah dan pemutus (penyelesai) atas sengketa dan problem di dalam keluarga. Penyelesaian yang digunakan pada saat itu dalam bentuk perdamaian atau disebut hakam, dan lembaganya disebut lembaga Tahkim. Setelah kondisi masyarakat sudah mulai teratur, namun belum memiliki pemerintahan, muncullah lembaga ahl al-halli wa al-'aqdi, dengan mengangkat ahli-ahli hukum Islam sebagai hakim atau qadhi oleh masyarakat dengan bentuk Peradilan Adat berdasarkan rapat marga, negeri dan semacamnya. Kemudian diikuti lembaga Peradilan Swapraja yang dibentuk setelah terbentuknya kerajaankerajaan Islam di Nusantara.

Pada perkembangannya, Peradilan Swapraja kemudian berubah nama menjadi Peradilan Agama. ${ }^{19}$ Dari sinilah penerapan hukum keluarga Islam mulai terorganisir dengan baik di dalam kerajaan dan masyarakat. Sebagai contoh adalah keterangan dari Nani Soewondo, ${ }^{20}$ di mana pada masa kerajaan, menikah dengan banyak perempuan (poligami) tanpa batas oleh rajaraja dan para bangsawan adalah hal yang biasa. Namun setelah muncul kodifikasi hukum keluarga ala asy-syafi'iyyah beserta pelembagaan hukumnya, maka mereka kemudian mengikuti aturan tersebut dengan mengumpulkan maksimal hanya empat istri saja dalam satu keluarga, meskipun menikahi banyak perempuan tetap dilakukan dengan cara menceraikan salah satu dari empat istri yang ada dan menikah kembali dengan wanita lain untuk mengisi quota empat orang istri sebagai jumlah maksimal dari poligami yang ditentukan agama.

Berdasarkan periode kedua di atas, di mana hukum Islam mulai terlembaga di dalam hukum kerajaan, termasuk hukum keluarga

19 Khoiruddin Nasution, Hukum Perdata (Keluarga) Islam Indonesia dan Perbandingan Hukum Perkawinan di Dunia Muslim: Studi Sejarah, Metode Pembaharuan dan Materi \& Status Perempuan dalam Undang-undang Perkawinan Muslim, (Yogyakarta: ACAdeMIA+TAZZAFA, 2009), h. 16-17; Zaini Ahmad Noeh, "Kepusakaan Jawa Sebagai Sumber Sejarah Perkembangan Hukum Islam", dalam Amrullah Ahmad, Dimensi Hukum Islam dalam Sistem Hukum Nasional, (Jakarta: Gema Insani Press, 1996), h. 72

20 Nani Soewondo, Kedudukan Wanita Indonesia dalam Hukum dan Masyarakat, (Jakarta: Timun Mas, 1968), Cet. Ke-2, h. 67-68 
Islam, maka ia dapat dimaknai sebagai sebuah seperangkat kaidah perundang-undangan yang mengatur hubungan personal anggota keluarga dalam konteksnya yang spesifik dalam hubungan hukum suatu keluarga muslim, dengan ruang lingkup kajiannya mencakup tema perkawinan (munakahat dan hal yang bertalian dengannya), perwalian, wasiat, dan kewarisan, ${ }^{21}$ meskipun rumusan berpikirnya masih terkotak pada satu manhaj fikih saja yakni asy-syafi'iyyah.

\section{Perkembangannya di Nusantara}

Bermula dari awal mula penetrasi Islam ke Indonesia yang berbeda-beda antara masing-masing wilayah (diawali pada abad ke $1 \mathrm{H}$ / VII M / tahun 630-an), namun dengan substansi yang sama, yakni membentuk identitas baru Islam dengan jalan memperkenalkan Islam yang ramah, bersih, toleran dan lain sebagainya melalui teori inkulturasi wahyu (asy-syari'ah) dengan budaya lokal yang hidup pada saat itu, maka produk-produk hukum yang muncul bersifat renungan dan kajian yang mendalam (ijtihad) berbasis epistemologis.

Paradigma filosofis dalam mencari hakikat kebenaran dilakukan dengan cara mengikuti model pengenalan dan penerapan hukum secara bertahap (at-tadarruj) yang diajarkan oleh Allah swt kepada Rasulullah Muhammad saw. Seperti dalam hal Islamisasi melalui jalan perkawinan dengan putriputri kerajaan (hasil hadiah sayembara ${ }^{22}$ ),

21 M. Amin Summa, Hukum Keluarga Islam di Dunia Islam, (Jakarta: RajaGrafindo Persada, 2004), h. 14 dan 30; Jamhari Makruf dan Tim Lindsey (ed.)., Hukum Keluarga, Pidana \& Bisnis: Kajian Perundang-undangan Indonesia, Fikih dan Hukum Internasional, (Jakarta: Kencana, 2013), h. 11

22 Sayembara adalah perlombaan (karang-mengarang dan lain sebagainya) dengan memperebutkan hadiah. Lihat Departemen Pendidikan Nasional, Kamus Besar Bahasa Indonesia, (Jakarta: Pusat Bahasa, 2008), h. 1276 di mana dapat dimaknai bahwa Islamisasi berlangsung setelah proses pernikahan dilaksanakan dan bukan sebelum pernikahan. Begitu juga dengan masalah kewarisan yang tidak diterapkan secara utuh di dalam aturan hukum dalam berrumah tangga muslim saat itu, di mana pembagian harta peninggalan keluarga yang meninggal hampir didominasi untuk disesuaikan pembagiannya dengan kearifan lokal yang hidup di dalam masyarakat, baik dibagi sebelum adanya kematian atau setelahnya, sehingga sampai saat ini masih banyak daerah-daerah yang memegang kuat prinsip keluarga berbasis parental, ${ }^{23}$ patrilineal, ${ }^{24}$ ataupun materlineal. ${ }^{25}$

Paradigma epistemologis tersebut bertransformasi secara total setelah terjadi perubahan kepentingan dan keadaan keislaman di Indonesia, dari yang pada awalnya fungsi penetrasi Islam sebagai cara untuk membentuk identitas baru, menjadi penguatan identitas setelah Islam tersebar ke seluruh penjuru Melayu-Nusantara.Demimenguatkan identitas tersebut maka ditulislah bukubuku yang menggunakan bahasa asli daerah (seperti bahasa Aceh, Bugis, Melayu, Jawa, dan lain-lain) atau melalui penerjemahan

Dalam kewarisan parental, seluruh harta kekayaan milik orang tua diwariskan samarata-samarasa kepada semua anaknya, dan jika salah seorang ahli waris meninggal dunia lebih dahulu dari pada pewarisnya, maka secara representasi semua anak si mati mendapatkan hak atas bagian warisan orang tuanya. Adapun jika tidak memiliki keturunan maka harta diserahkan kepada kelompok kerabat suami atau istri yang masih hidup. Lihat Iman Sudiyat, Hukum Adat: Sketsa Asas, (Yogyakarta: Liberty, 1981), h. 12

24 Dalam kewarisan patrilineal, ahli waris hanya milik anak lakilaki, karena anak-anak perempuan keluar dari kelompok keraban gens patrilinealnya semula. Jika tidak memiliki anak maka warisannya jatuh ke tangan bapak si pewaris, dan jika bapaknya juga telah meninggal, maka warisan tersebut menjadi miliki saudara laki-laki si pewaris. Ibid., h. 12-13

25 Dalam kewarisan matrilineal ini, semua anak mewarisi harta kekayaan ibunya, kerena bapaknya institusional tetap tinggal dalam kelompok clan matrilinealnya semula. Ibid., h. 13 
dari bahasa Arab ke dalam bahasa Melayu atau Jawa, yang bertemakan hukum Islam dengan genealogi arus pemikirannya adalah mazhab asy-syafi'iyyah yang bersifat teologisnormatif-deduktif.

Pembangunan paradigma seperti ini terjadi sejak abad ke-16 atau tahun 1641 dengan diangkatnya Ar-Raniry sebagai qadhi malik al-'adil oleh pemerintahan Iskandar Tsani dan menulis sebuah buku atas perintah raja, sebagai rujukan utama pemberlakuan hukum Islam (fiqh) di bumi Serambi Mekah dengan judul as-Sirath al-Mustaqim. Semangat ini dilanjutkan oleh penerusnya yakni AsSingkili dengan menulis sebuah buku berjudul Mir'ah at-Thullab fi Tashil Ma'rifah al-Ahkam wa asy-Syar'iyyah.

Pada dimensi ini, pertemuan antara Islam dengan budaya lokal terjadi dalam bentuk penerjemahan bahasa atas buku-buku fiqh asy-Syafi'iyyah yang berbahasa Arab semata tanpa melihat substansi dari sebuah hukum tersebut dengan melacak langsung pada sisi epistemologisnya. Namun dalam pandangan Akh. Minhaji, fase tersebutmemberi gambaran bahwa hukum Islam (fiqh) telah membumi bagi masyarakat, dan dirasakan manfaatnya oleh mereka, di mana jika sebelumnya hanya penguasa yang memiliki kewenangan dalam menggunakan hukum, tapi kini ulama mulai memberikan fatwa terhadap setiap problem hukum di dalam masyarakat dengan rujukan kitab-kitab tersebut. ${ }^{26}$

Implikasi dari hasil copy-paste atas pemikiran fiqh Syafi'iyyah yang merupakan produk al-Haramain dan Baghdad (qaul qadim)

26 Lihat Akh. Minhaji, “Arah Baru Studi Hukum Islam di Indonesia”, Hasil Revisi Makalah, Dipresentasikan dalam Semiloka Pembandingan Keilmuan Agama Islam dengan judul "Dimensi HistorisEpistemologis bidang Keilmuan Hukum Islam dan Pranata Sosial serta Orientasi Pengembangannya di IAIN/STAIN", Lembaga Kajian Islam dan Masyarakat (LKIM) STAIN Mataram, 12-13 September 2003, h. 7 serta Mesir (qaul jadid) ternyata sangat kuat melekat dibenak para ulama Nusantara sehingga sulit untuk menerima adanya perbedaan pemikiran dan pembaharuan hukum yang progresif karena dianggap liberal. Bahkan dalam kerangka pikir hukum keluarga, penguatan paham teologis-fiqhiyyah begitu kental. Sebagai contoh adalah, tentang jalur peraih harta waris dari golongan laki-laki dan perempuan sebagaimana yang tertuang di dalam kitab I'anah ath-Thalibin:

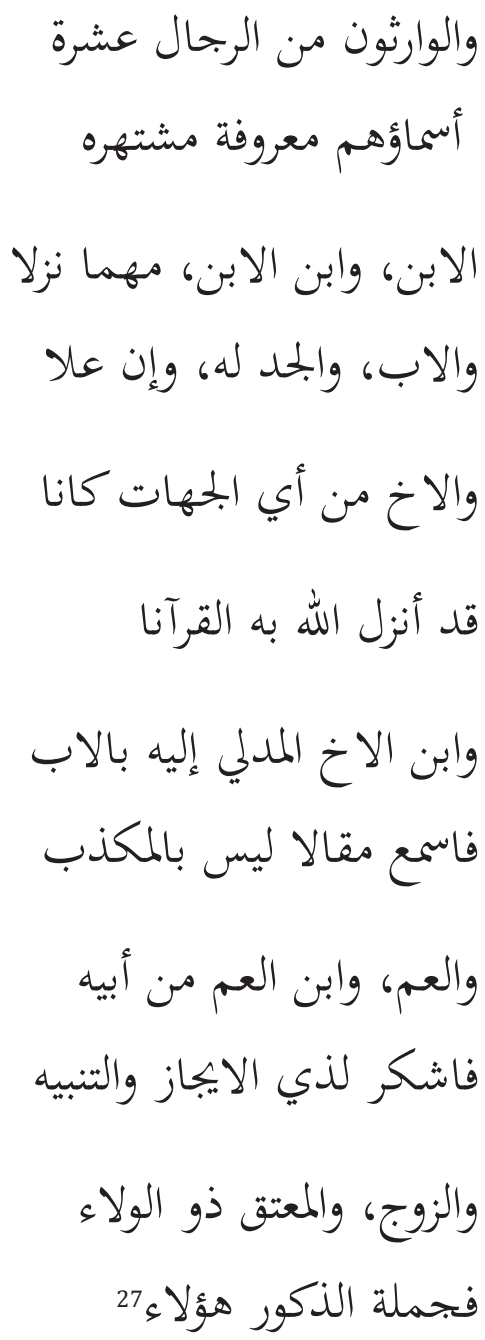

Artinya : "Kaum pria yang mendapat bagian warisan ada sepuluh, yakni (1) anak laki-laki, (2) cucu laki-laki dari anak laki-laki terus ke bawah, (3)

\footnotetext{
As-Sayyid al-Bakri bin al-Sayyid Muhammad Syathan adDimyathi, Hasyiyah I'anah at-Thalibin, (Indonesia: al-Haramin, 2001), Jil. 3, h. 224
} 
ayah, (4) kakek dari ayah terus ke atas, (5) saudara laki-laki seayah dan seibu sebagaimana yang dijelaskan Allah di dalam al-Qur'an, (6) anak laki-laki dari saudara laki-laki seayah, perhatikan baik-baik ini bukan pendusta, (7) paman dari ayah, (8) anak paman dari ayah maka bersyukurlah atas ketentuan ini, (9) suami, (10) orang laki-laki yang memerdekakan hamba sahaya, itulah mereka."

Adapun dari kelompok perempuan ada tujuh :

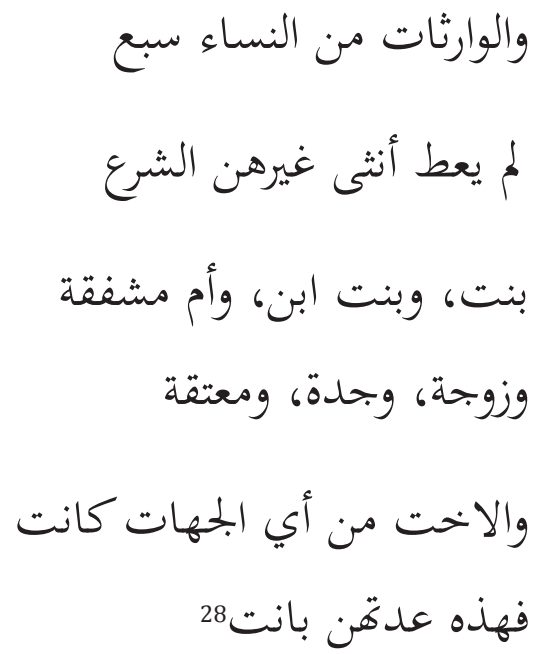

Artinya : "Perempuan-perempuan yang mendapatkan harta waris ada tujuh, selain mereka tidak boleh menerima sesuai syariat, (1) anak perempuan, (2) сисu perempuan dari anak lakilaki, (3) ibu kandung, (4) istri, (5) nenek dari ayah, (6) perempuan yang memerdekakan hamba sahaya, (7) saudara perempuan seibu dan seayah, itulah mereka."

Klasifikasi ahli waris yang dibuat oleh ad-Dimyathi menurutnya dirujuk langsung dari al-Quran al-Karim, di mana penunjukkan ayah yang lurus ke atas sampai ke kakek dari garis laki-laki yang didasarkan atas firman Allah swt, wa li abawaihi likulli wahid minhuma as-sudus mimma taraka inkana lahu walad. Penunjukan anak dan cucu ke bawah dari garis laki-laki, sebagaimana firman Allah swt, yushikumullah fi awladikum. Kemudian jalur ke samping yang menjadikan paman, saudara, semuanya juga dari garis ayah. Begitu juga dengan kalalah, yakni mereka yang mati hanya memiliki saudara laki-laki atau perempuan seibu, semuanya dapat harta waris harus karena tidak memiliki anak ke bawah dan tidak ada ayah ke atas.

Selanjutnya adalah masalah penghalang (hujub/hijab) dalam pembagian harta waris, di mana mereka yang terhijab secara hirman ada tujuh, yakni kakek, nenek, beberapa saudara perempuan sekandung, beberapa saudara perempuan seayah, anak-anak ibu, anak-anak perempuan dari anak laki-laki, dan seorang anak laki-laki dari anak laki-laki. Dalam hal ini, kakek terhijab oleh ayah, nenek oleh ibu, dua orang sudara sekandung oleh anak laki-laki, anak-laki-laki dari anak lakilaki oleh ayah. Saudara-saudara perempuan seayah oleh anak laki-laki, saudara laki-laki seibu terhijab oleh ayah, kakek, anak dan cucu. Anak-anak perempuan dari anak lakilaki terhijab oleh anak laki-laki dan anak laki-laki dari anak laki-laki terhijab oleh anak laki-laki. ${ }^{29}$ Pada bagian ini, dominasi kaum laki-laki dalam melakukan penghijaban atau penghalangan pembagian waris hampir terjadi di semua lini.

Penjelasan fiqhiyyah mazhab asy-Syafi'i di atas tentang dominasi laki-laki dalam pembagian harta peninggalan mayit (tirkah), menjadi pegangan kuat bagi kelompok

29 Wahbah Zuhaili, al-Fiqh al-Islami wa Adillatuhu, Penerjemah Abdul Hayyie al-Kattani dkk., (Jakarta: Gema Insani, 2011), Jilid. 10 , h. 428 
tradisionalis-konservatif tentang dominasi laki-laki tersebut dan bukan pada substansi pembagiannya. Dengan pemahaman teologifiqhiyyah di hampir seluruh materi-materi fikih, di mana aturan-aturan fikih bersinergi dengan keimanan, sehingga akibatnya, jika seseorang tidak melaksanakan aturan fikih yang ada, maka berakibat sama dengan tidak beragama dan terindikasi masuk ke dalam neraka. Ketidaksamaan dalam berfikih adalah kedurhakaan, ikhtilaf (perbedaan pendapat) hanya milik para ulama' dan tidak layak bagi masyarakat awam untuk ber-talfiq apalagi berijtihad.

Perjalanan budaya hukum keluarga seperti di atas terus berlangsung hingga masa kolonial Belanda dan Jepang, yakni budaya hukum yang diselimuti keterbelakangan dalam berpikir, tersudut pada aspek ibadah, bercorak satu mazhab, memperteguh semangat taqlid, larangan talfiq dan menutup pintu ijtihad, miskinnya kajian metodologis, pemikiran yang lebih mementingkan hasil daripada proses penyimpulan hukum, mengabaikan jalb al-mashalih wa dar'u almafasid sebagai salah satu tujuan hukum Islam, pendapat ulama di-copy-paste sebagai sebuah kebenaran tanpa mau mengkaji ulang, bahkan Islam selanjutnya lebih dipahami sebagai proses Arabisasi dengan menegasi nilai-nilai kearifan lokal. Hal ini diperparah lagi dengan lahirnya teori receptie yang dikumandangkan oleh kolonial Belanda berdasarkan hasil pemikiran Snouck Hurgrunje, di mana hukum Islam baru dapat diterima ketika bersinergi dengan hukum adat dan terresepsi ke dalamnya.

Proses seperti ini berjalan cukup lama dari mulai kelahirannya di tahun 1641 hingga hadir penggugat pertama yang bernama Hasbi ash-Shiddieqy di tahun 1940 dengan menelurkan istilah "Fiqh Indonesia" yang baru didefinisikan olehnya ditahun pada 1961 sebagai fikih yang yang ditentukan berdasarkan kepribadian dan karakter bangsa Indonesia. $^{30}$ Dilanjutkan setelah itu oleh Hazairin yang melakukan kritik atas konsep kewarisan Islam dengan menelurkan satu buah teori kewarisan bilateral dan kemudian menggagas konsep "Mazhab Nasional" di tahun 1950-an. Artinya, butuh lebih dari 300 tahun untuk menghadirkan gagasan-gagasan pembaharuan hukum Islam di Indonesia dengan indegenous ke-Indonesiaan, yang berusaha membebaskan hukum Islam dari adat Arab karena dalam kerangka ini, Islam tidak berarti Arab.

Dalam konsep Hazairin, sistem kemasyarakatan yang terkandung dalam al-Qur'an adalah sistem kemasyarakatan bilateral, dan karenanya sistem kewarisannya pun bercorak bilateral pula. Allah swt berfiman: Ia merujuk dan menyimpulkan ini, dengan mendasarkan pada surat an-Nisa' ayat 23 dan 24 :

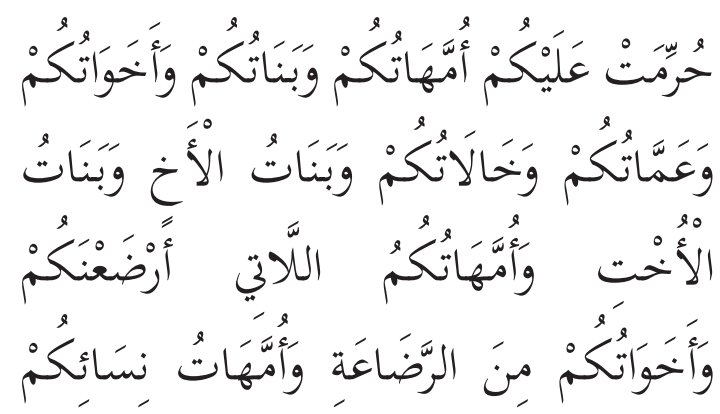

Hasbi Ash Shiddieqy, Syari'at Islam Menjawab Tantangan Zaman, (Yogyakarta: IAIN Sunan Kalijaga, 1961), h. 24; Konsep Fiqh Indonesia di atas dalam perjalanannya pernah mendapatkan penolakan yang keras dari para pemikir Islam seperti Kuntowijoyo, Ali Yafie dan Ibrahim Hosen. Sebagaimana penjelasan dari Kuntowijoyo, "Dalam konteks Indonesianisasi, Islam telah menimbulkan perlawanan pada tingkat tertentu. Dengan kata lain, rasionalisasi Islam telah jatuh, menjadi mistis, dan lokal dalam hal budaya. Karena itu, kita bisa bertanya, jika seseorang ingin Indonesia 'menjadi' Islam, maka arah mana yang harus ia tempuh?... karena Islam di Indonesia telah jatuh dari universal ke tahap lokal? Jika harus ada Indonesianisasi, lalu apa bentuknya (dari Islam yang diindonesiakan) itu?". Lihat Kuntowijoyo, Dinamika Sejarah Umat Islam Indonesia, (Yogyakarta: Salahuddin Press, 1984), h. 43-44 


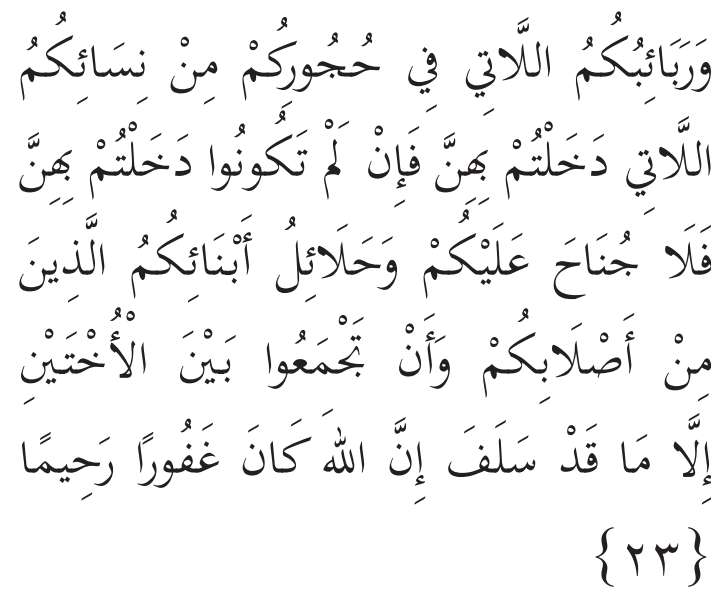

Artinya: "Diharamkan atas kamu (mengawini) ibu-ibumu; anak-anakmu yang perempuan; saudara-saudaramu yang perempuan, saudara-saudara bapakmu yang perempuan; saudarasaudara ibumu yang perempuan; anak-anak perempuan dari saudarasaudaramu yang laki-laki; anak-anak perempuan dari saudara-saudaramu yang perempuan; ibu-ibumu yang menyusui kamu; saudara perempuan sepersusuan; ibu-ibu isterimu (mertua); anak-anak isterimu yang dalam pemeliharaanmu dari isteri yang telah kamu campuri, tetapi jika kamu belum campur dengan isterimu itu (dan sudah kamu ceraikan), maka tidak berdosa kamu mengawininya; (dan diharamkan bagimu) isteri-isteri anak kandungmu (menantu); dan menghimpunkan (dalam perkawinan) dua perempuan yang bersaudara, kecuali yang telah terjadi pada masa lampau; sesungguhnya Allah Maha Pengampun lagi Maha Penyayang."

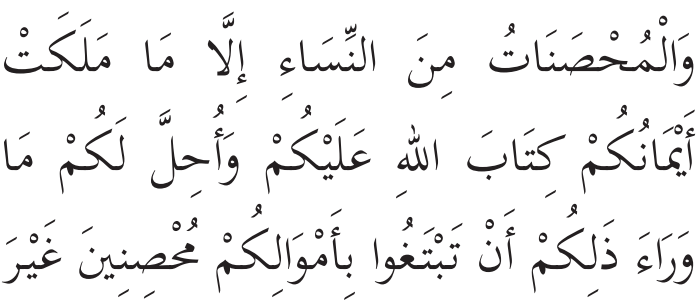

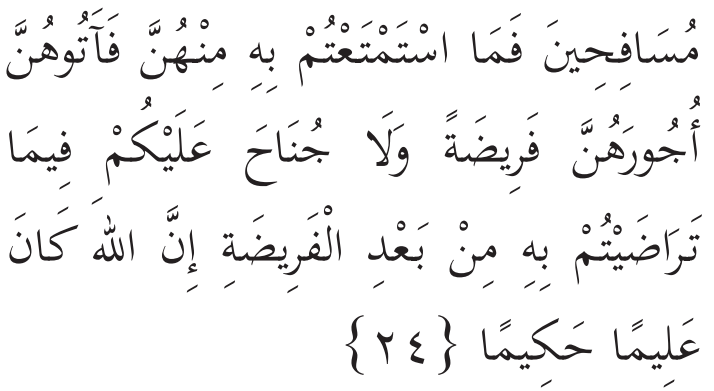

Artinya : "Dan (diharamkan juga kamu mengawini) wanita yang bersuami, kecuali budak-budak yang kamu miliki (Allah telah menetapkan hukum itu) sebagai ketetapan-Nya atas kamu. Dan dihalalkan bagi kamu selain yang demikian (yaitu) mencari isteri-isteri dengan hartamu untuk dikawini bukan untuk berzina. Maka isteri-isteri yang telah kamu nikmati (campuri) di antara mereka, berikanlah kepada mereka maharnya (dengan sempurna), sebagai suatu kewajiban; dan tiadalah mengapa bagi kamu terhadap sesuatu yang kamu telah saling merelakannya, sesudah menentukan mahar itu. Sesungguhnya Allah Maha Mengetahui lagi Maha Bijaksana."

Menurut Abdul Ghoni, ${ }^{31}$ berdasarkan hasil penelitian Hazairin terhadap hukum adat yang berlaku di beberapa daerah Indonesia, ia menyatakan bahwa hukum kewarisan Sunni yang bercorak patrilineal itu, bukannya tidak ada masalah (konflik) dengan hukum patrilineal yang ada di lndonesia, dan konflik-konflik itu sendiri bukan disebabkan oleh kitab suci al-Qur'an, tetapi oleh ikhtilaf manusia itu sendiri. ${ }^{32}$ Teori Hazairin tersebut didasarkan pada penyelidikamya terhadap

\footnotetext{
31 Abdul Ghoni Hamid, "Kewarisan dalam Perspektif Hazairin", Jurnal Studi Agama dan Masyarakat, Vol. 4, No. 1, Juni 2007, h. 42-45

32 Hazairin, Hukum Kewarisan Bilateral Menurut al-Qur'an dan Hadith, (Jakarta: Tintamas, 1982), Cet. Ke-6, h. 1-2
} 
hukum Islam yang memberikan perhatian istimewa kepada bagian hukum kekeluargaan, yang telah berhasil mendapatkan pengertian yang esensial tentang ayat 23 dan 24 surat anNisa', dengan pendekatan ilmu antropologi sosial. $^{33}$

Menurut Hazairin, sistem kewarisan berintikan pada sistem keluarga, sedangkan keluarga berintikan pada sistem perkawinan dan kedua inti itu menentukan bentuk sistem kemasyarakatan dari suatu bangsa yang kembali mempengaruhi sistem perkawinan dan kewarisannya. ${ }^{34}$ Berdasarkan semangat pembaharuan itulah lalu pada tahun 1970an muncul perdebatan di dalam parleman mengenai rumusan UU perkawinan yang diajukan oleh pemerintah dan baru disahkan pada tahun 1974, dengan nama UU No. 1 tahun 1974 tentang Perkawinan.

Jika dilihat dari perkembangan pembaharuan hukum keluarga di dunia muslim, maka sesungguhnya Indonesia telah tertinggal dalam melakukan pembaharuan hukum keluarga. ${ }^{35}$ Hal ini diperparah lagi dengan

33 Lebih detil lagi prinsip-prinsip metodologi dan metode yang digunakan Hazairin terhadap pemikiran pembaruan hukum kewarisan Islam dapat disarikan sebagai berikut: (1) Pendekatan antropologi sosial (Indonesia), (2) Pendekatan hukum adat dengan receptie exit theory, (3) Menggunakan pola postivikasi hukum John Austin, (4) Konsep kewarisan (wasiat wajibah) Hazairin dipengaruhi oleh Hukum Sipil Perancis, (5) Menggunakan metode tematikholistik dan menolak teori naskh, (6) Menggunakan metode 'ibarat an-nash (pemahaman eksplisit), dan (7) Menggunakan pola qiyas induktif dan deduktif. Lihat Moh. Mukri, "Dinamika Pemikiran Fikih Mazhab Indonesia: Perspektif Sejarah Sosial”, Analisis, Vol. XI, No. 2, Desember 2011, h. 202; dikutip dari Hazairin, Hukum Kekeluargaan Nasional, (Jakarta: Tintamas, 1982), h. 24

34 Abdul Halim, "Hazairin dan Pemikirannya tentang Pembaharuan Hukum Kekeluargaan dalam Islam", Penelitian Jurnal Agama, No. 18, Th. VII, 1998, h. 134-135

35 Periodesasi pembaharuan hukum keluarga Islam di negaranegara muslim secara global dikelompokkan menjadi tiga fase; (1) Fase tahun 1915-1950, (2) Fase tahun 1950-1971, dan (3) Fase tahun 1971 sampai saat ini. Dan Indonesia termasuk yang terbelakang dalam melakukan pembaharuan karena baru di tahun 1974 mampu melahirkan undang-undang tentang Perkawinan, dan di tahun 1991 melahirkan Inpres tentang penungguan yang lama (17 tahun) dalam memproduksi aturan penggerakanya untuk masyarakat muslim Indonesia yang hanya berupa Instruksi Presiden No. 1 Tahun 1991 tentang Kompilasi Hukum Islam. Meskipun demikian, semangat pembaharuan ini tidaklah terlambat, karena dalam pandangan pembaharuan hukum Islam, ada tiga alasan kuat yang mendorong negara-negara Islam melakukan pembaharuan hukum keluarga : (a) Untuk tujuan unifikasi (penyatuan) hukum. Usaha unifikasi dilakukan karena masyarakatnya menganut mazhab atau bahkan agama yang berbeda-beda; (b) Untuk tujuan meningkatkan status perempuan. Meskipun tujuan ini tidak disebutkan secara eksplisit, namun sangat terasa bahwa undang-undang tersebut merespon tuntutantuntutan peningkatan status dan kedudukan perempuan; (c) Untuk merespon tuntutan zaman dan dinamika perkembangan masyarakat akibat perkembangan global dalam seluruh aspek kehidupan manusia. ${ }^{36}$ Dalam konteks ke-Indonesiaan, ada dua tema besar pembaharuan melalui reformasi hukum Islam termasuk pada sub hukum keluarga, yakni (1) kembali kepada al-Quran dan as-Sunnah, dan (2) tema ke-Indonesiaan. ${ }^{37}$

Selanjutnya dalam tataran implementatif, Undang-undang Nomor 1 Tahun 1974 tentang Perkawinan dan Kompilasi Hukum Islam ternyata belum membumi di Indonesia. Terbukti, bahwa umat Islam masih lebih

Kompilasi Hukum Islam. Mengenai periodesasi ini, lihat Khoiruddin Nasution, Pengantar dan Pemikiran Hukum Keluarga (Perdata) Islam Indonesia, (Yogyakarta: ACAdeMIA+TAZZAFA, 2010), h. 32-39

36 Siti Musdah Mulia, "Pembaharuan Hukum Keluarga Islam di Indonesia", dalam Komaruddin Hidayat dan Ahmad Gaus AF [ed.], Islam Negara \& Civil Society ; Gerakan dan Pemikiran Islam Kontemporer, (Jakarta: Paramadina, 2005), h. 306

37 Yudian K. Wahyudi, Ushul Fikih versus Hermeneutika: Membaca Islam dari Kanada dan Amerika, (Yogyakarta: Pesantren Nawesea Press, 2007), Cet. Ke-5, h. 36 


\section{PERIODESASI EVOLUSI BUDAYA HUKUM KELUARGA ISLAM DI INDONESIA}

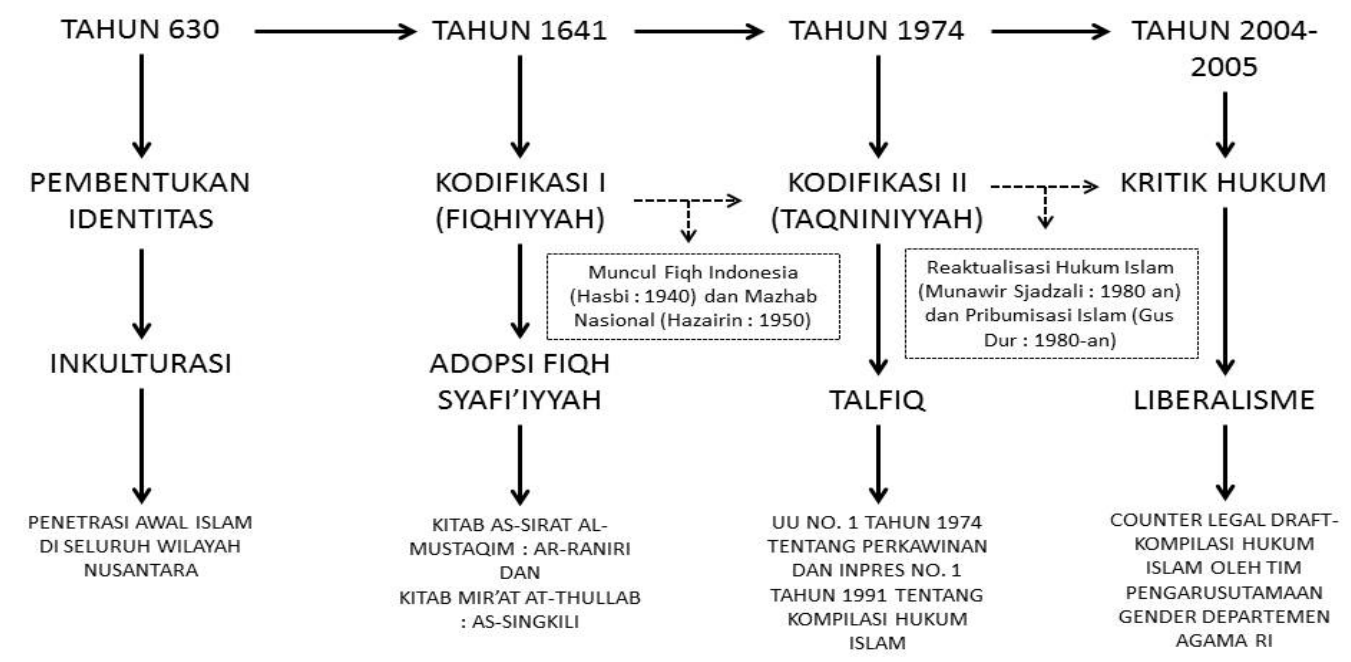

memilih aturan fikih daripada aturan hukum dari pemerintah di atas, dengan banyaknya kasus perkawinan di bawah tangan, bahkan dilakukan oleh pejabat negara sebagai pelaksana undang-undang. Perceraian gantung karena merasa akan berjalan sulitjika dimasukkan berkas perkaranyake Pengadilan. Pernikahan yang terjadi dengan status dusta, seperti wanita yang masih digantung percerainnya, mengaku single padahal masih berstatus menikah dengan orang lain. Masih banyak lagi kasus-kasus lain yang belum terjamah dalam renungan dan kajian ilmiah. Meskipun demikian, semangat pembaharuan tetap ada di dalam aturan hukum tersebut, berupa diperbolehkannya wanita (istri) untuk mengajukkan permohonan cerai ke Pengadilan, yang kemudian dikenal dengan istilah cerai gugat.

Jika dilihat dari segi fikih yang diajarkan di hampir seluruh wilayah di Nusantara dahulu, maka sikap istri yang meminta cerai terhadap suaminya adalah perbuatan dosa besar di hadapan Allah swt, dan dinilai sebagai pelanggaran terhadap ajaran agama karena melakukan perlawanan terhadap suami (nusyuz). Begitu juga dengan hak ijbar (memaksa) dan adhal (menolak) yang tidak begitu saja langsung diimplementasikan dalam aturan perkawinan di Indonesia. ${ }^{38}$ Bahkan, ketika seorang wali merasa enggan (adhal) maka wali hakim dapat melaksanakan pernikahan setelah mendapatkan persetujuan dan putusan dari Pengadilan Agama. ${ }^{39}$

Oleh karena minimnya pembaharuan hukum keluarga di atas, juga kerena dominasi teologi-fiqhiyyah yang masih begitu kuat menyelimuti aturan hukum tersebut, maka lahirlah para penggugat hukum Islam sebelum lahirnya KHI melalui konsep "Reaktualisasi Hukum Islam" yang dihasilkan oleh Menteri Agama RI Ke-13 Munawir Sjadzali di tahun 1980-an, dan konsep "Pribumisasi Islam" oleh Abdurrahman Wahid (Gus Dur) pada tahun yang sama. Namun semangat pembaharuan

38 Aturan tentang perkawinan harus mendapat persetujuan dari kedua orang yang akan menikah, dan perkawinan akan batal ketika salah satu calon mempelai tidak menyetujuinya, menunjukkan bahwa hak wali untuk memaksa pernikahan dengan kehendak wali dengan serta merta tertolak. Lihat pasal 6 ayat (1) UU No. 1 Th. 1974 dan pasal 16 ayat (1) dan (2) KHI.

39 Lihat KHI pasal 23 ayat (2). 
pemikiran ini ternyata tidak begitu kuat, terbukti oleh mereka di dalam KHI masih begitu kental produk fiqh-nya ala mazhab Arab-Islam yang beralur pikir teologisnormatif-deduktif. Sehingga pascareformasi (tahun 1999) muncul semangat baru yang lebih progresif dengan melakukan kritikankritikan yang tajam terhadap KHI melalui diskusi-diskusi yang dilakukan oleh para akademisi Islam dan diakomodir oleh pemerintah melalui Tim Pengarusutamaan Gender Departemen Agama RI pada tahun 2004-nya. ${ }^{40}$ Namun riwayat hidup tim kerja tersebut ternyata tidak berlangsung lama, akibat Menteri Agama RI yang baru dilantik pada tahun 2005 langsung membubarkan proyek kerja CLD-KHI karena dianggap berafiliasi dengan pemikiran Liberalisme Islam dan menggangu stabilitas sosialkeagamaan di dalam masyarakat.

Melalui periodisasi evolusi budaya hukum keluarga Islam tersebut, akan digambarkan betapa semangat kodifikasi hukum - sebagai bentuk perkembangan hukum keluarga Islam di Indonesia - secara alamiah telah mengeleminir khazanah keilmuan Islam yang begitu luas menjadi Arabisasi. Meskipun demikian, perubahan persepsi ini tidak dapat dihindari karena perubahan zaman di era demokrasi telah menjadikan hukum sebagai panglima, maka menganulir hukum dalam kehidupan bernegara sama saja dengan menolak takdir dari setiap individu manusia, dan dalam konteks hukum keluarga Islam, ia

\footnotetext{
40 Pada tanggal 4 Oktober 2004 di Jakarta oleh Pokja Pengarusutamaan Gender Departemen Agama RI me-launching Counter Legal Draft Kompilasi Hukum Islam (CLD-KHI). CLDKHI tersebut dipersiapkan sebagai hukum materiil Islam dalam bidang perkawinan sebanyak 116 pasal, kewarisan sebanyak 42 pasal dan perwakafan sebanyak 20 pasal. Komnas Perempuan, "Dokumen Nasional: Penerapan Hukum Keluarga Islam di Indnoesia", Hasil kesepakatan bersama dalam Konstultasi Nasional: Mencapai Hukum Keluarga yang Adil dan Setara Gender, Jakarta: Hotel Harris, 3-4 Februari 2009, h. 5
}

hanya dapat berlaku secara yuridis di bumi Indonesia apabila telah terkodifikasi dalam perundang-undangan nasional.

Kreasi historis yang telah dituangkan di atas, menggambarkan bahwa budaya hukum keluarga di Nusantara telah mengalami evolusi secara komprehensif ketika Islam mulai melakukan penetrasi. Perubahan tersebut sesuai dengan teori dialektika berupa upaya yang bersifat continue selama manusia di dalam masyarakat ingin terus mencari kebaikan-kebaikan sehingga apa yang dirasakan baik dan sempurna pada hari ini (tesa), belum tentu akan dirasakan sama pada masa yang akan datang (antitesa), sehingga dibutuhkan solusi baru sebagai sintesa-nya.

Oleh karena itu, budaya hukum yang ada di Nusantara sebelum datangnya Islam merupakan tesa yang dirasakan baik dan sempurna pada saat itu. Namun semua menjadi antitesa ketika Islam datang melalui dua teori Islamisasi yakni inkulturasi pada tahap awal dan akulturasi pada tahap pembentukan hukum, sehingga menarik simpati masyarakat dan secara sukarela melakukan konversi atas keyakinan mereka menjadi muslim. Perubahan budaya hukum tersebut menjadi budaya hukum Islam yang kemudian dirasa nyaman untuk terus diimplementasikan dalam kehidupan seharihari termasuk dalam hal hukum keluarga selanjutnya menjadi sintesa, yang dalam waktu penerapannya yang panjang di dalam masyarakat maka kemudian ia menjadi tesa baru lagi di dalam masyarakat muslim Indonesia.

Evolusi budaya hukum keluarga di atas dalam pertemuannya dengan Islam terjadi secara dua arah yang saling mengisi antara satu sama lainnya - sebagaimana teori sibernitika Talcott Parsons - di mana sistem 
budaya memberi informasi untuk malakukan kontrol, plus menerima energi antara satu sama lain yang dimulai dari sistem sosial, lalu ke sistem personal, hingga sistem organisasi, dengan konsep dasarnya adalah, perubahan tidak hanya terjadi secara top-down akan tetapi juga harus melalui aspirasi dari bawah (bottom-up).

Ilustrasinya adalah, bahwa sebelum Islam datang sistem budaya di Indonesia sangat terikat pada budaya nenek moyang yang menguatkan genealogis mereka masing-masing, dengan model pernikahan mereka adalah endogami dan exogami. Dari sinilah kemudian sistem sosial, personal dan organisasi mereka terbentuk dalam kategori patrilineal dan matrilineal. Namun setelah Islam datang, dengan membawa ajaran ketauhidan, kemanusiaan dan nilai-nilai toleransi melalui jalan inkulturasi, maka terjadilah perubahan di dalam masyarakat dalam kategori bilateral atau parental dengan model perkawinannya adalah eleutherogami, dan model seperti ini menurut Surojo ${ }^{41}$ banyak berlaku pada masyarakat adat di Indonesia terutama yang banyak dipengaruhi hukum Islam.

Ketika perubahan model Islamisasi berubah ke model akulturasi di mana ArabIslam masuk dan merasuk ke dalam sistem organisasi sehingga terlembaga pada fiqh asy-syafi'iyyah, maka sistem personal pun berubah dengan sendirinya menjadi stagnan, menguatkan semangat taklid dan memunculkan ide pelarangan talfiq. Implikasi langsung dari perubahan sistem personal tersebut di dalam sistem sosial adalah ta'ashub bi almadzhab sehingga menegasi segala sesuatu yang lahir di luar mazhab tersebut meskipun

Surojo Wignjodipuro, Pengantar dan Azas-azas Hukum Adat, (Bandung: Alumni, 1971), h. 167; Hilman Hadikusuma, Hukum Perkawinan Adat, (Bandung: PT. Citra Aditya Bakti, 1995), Cet. Ke-5, h. 67 memiliki kebaikan secara komprehensif. Pada akhirnya, lahirlah sistem budaya baru di dalam masyarakat muslim Indonesia yang enggan untuk melakukan perubahan hukum, termasuk dalam hal hukum keluarga Islam, karena menganggap fikih mereka berlaku secara teologis beserta implikasinya.

Akibatdarievolusibudayahukumkeluarga Islam di Nusantara yang menjadi Arabisasi, ternyata menggugah beberapa pemikir Islam untuk menelurkan ide-ide pembaharuan yang diasumsikan sesuai dengan ruh bangsa Indonesia, seperti ide aktualisasi hukum Islam ala Munawir dan pribumisasi Islam ala Gus Dur. Dua ide besar yang sama-sama lahir di tahun 1980-an ini memiliki perbedaan yang sangat signifikan, karena ide aktualisasi lebih pada pembacaan ulang atas teks-teks agama melalui pendekatan yang ternyata juga lahir dari dunia Arab, yakni al-mashlahah at-Tufi dan kaidah perubahan hukum ala Abu Yusuf. Sedangkan teori pribumsasi Islam oleh Gus Dur - meskipun contoh yang dikeluarkannya tidak sebesar gaungnya - memberikan pemahaman yang kuat tentang pentingnya memahami Islam dan budaya lokal besera kearifannya, sehingga mampu bersikap toleran atas segala perbedaan yang ada di bumi Indonesia ini.

Jika kedua teori ini diikat menjadi satu, maka ia akan menghasilkan makna, bahwa dalam memahami Islam tidaklah dapatmelalui kulit luarnya saja yang terangkum dalam fikih yang lahir dari Arab, akan tetapi perlu dilakukan pembacaan ulang langsung pada sumber primernya agar mendapatkan nilai maslahat dan kemudian dipribumisasikan dalam konstruk Islam Indonesia. Namun ketika paradigma ini akan diaktualisasikan, ternyata belum ada sama sekali rumusan metodologis yang komprehensif, sehingga 
masih akan menampilkan polemik baru di dalam masyarakat karena akan dianggap melangit. Inilah sumber utama dari permasalahan yang ada selama ini, yakni pada perubahan metode Islamisasi dari inkulturasi wahyu asy-syari'ah dengan konstruk budaya lokal menjadi akulturasi Arab-Islam ke dalam budaya hukum Indonesia menjadi fiqh asysyafi'iyyah.

Demi membangunan hukum keluarga Islam Nusantara yang responsif, haruslah dengan mengembalikan metode inkulturasi sebagai basis metodologisnya yang berorientasi konstitusional, ${ }^{42}$ dan menjadikan metode akulturasi hanya sebagai pengayaan materi hukum, dan tidak dijadikan sebagai metode primer. Inspirasi utama dari itu semua bisa didapatkan dari hasil kerja keras Hazairin dalam menemukan asas bilateral di dalam al-Quran, di bawah bayang-bayang fiqh asysyafi'iyyah yang patrilineal pada saat itu.

\section{E. Kesimpulan}

Sejarah pembentukan dan pembaruan hukum keluarga Islam di Nusantara telah

\footnotetext{
${ }^{4}$ Ide konstitusionalisasi keindonesiaan bersumber dari dua kecenderuangan utama dalam tema gerakan "keindonesiaan" yang disebutkan oleh Yudian Wahyudi, yakni : (1) Cita-cita untuk membangun hukum Islam yang berciri khas Indonesia dengan cara membebaskan budaya Indonesia dari budaya Arab dan menjadikan adat Indonesia sebagai salah satu sumber hukum Islam di Indonesia. Kecenderuangan pertama ini ditandai dengan munculnya konsep Fiqh Indonesia oleh Hasbi di tahun 1940, Mazhab Nasional oleh Hazairin di tahun 1950-an, Pribumisasi Islam oleh Gus Dur di tahun 1988, dan Zakat sebagai Pajak oleh Masdar Farid Mas'udi di tahun 1991. (2) Keindonesian yang berorientasi konstitusional. Tema gerakan ini dimotori oleh tokoh-tokoh umum yang menguasai sistem hukum Indonesia, tetapi kurang mendalami prinsip-prinsip "kembali kepada alQur'an dan as-Sunnah", dengan tahap orientasi dari sikap yang keras kemudian lunak. Lihat Yudian Wahyudi, Hasbi's Theory of Ijtihad in the Context of Indonesian Fiqh, (Yogyakarta: Pesantren Nawesea Press, 2007), h. 37-38; Mansur, "Kontekstualisasi Gagasan Fiqh Indonesia T.M. Hasbi Ash-Shiddieqy; Telaah atas Pemikiran Kritis Yudian Wahyudi", ASY-SYIR'AH Jurnal Ilmu Syari'ah dan Hukum, Vol. 46, No. 1, Januari-Juni 2012, h. 37
}

mengalami berbagai fase evaluasi dan evolusi, dari mulai penerapan model inkulturasi hingga tereduksi dengan model akulturasi. Fase akulturasi merupakan fase terlama dan terkuat karena dominasi pembelajaran ilmu-ilmu keislaman termasuk hukum keluarga dari satu mazhab fikih, yakni mazhab asy-syafi'iyyah. Meskipun demikian, bukan berarti para pemikir Islam tidak melakukan kritik dan evaluasi atas stagnasi ilmu tersebut, karena pada era 50-an muncul Hazairin dan Hasbi Ash Shiddieqy yang memunculkan istilah dan teori hukum Islam yang mencirikan ke-Indonesiaan, dan pada era reformasi lahir pula para pemikir-pemikir Islam yang kembali menggugat hukum keluarga di Indonesia dengan menghadirkan CLD-KHI, meskipun semuanya secara politik gagal untuk dilembagakan dalam bentuk perundang-undangan.

\section{DAFTAR PUSTAKA}

ad-Dimyathi, As-Sayyid al-Bakri bin al-Sayyid Muhammad Syathan., Hasyiyah

I'anah at-Thalibin, Indonesia: al-Haramin, 2001.

Ahmad, Amrullah, dkk., Dimensi Hukum Islam dalam Sistem Hukum Nasional, J a ka r ta: Gema Insani Press, 1996.

al-Qaththan, Manna',, Tarikh at-Tasyri' alIslami, Kairo: Maktabah Wahbah, t.th ar-Razi, Fakhr ad-Din., Mafatih al-Ghaib, Beirut: Dar al-Fikr, 1995.

ath-Thabari, Abu Ja'far Muhammad ibn Jarir., Jami' al-Bayan 'an Ta'wil al- Qu r'an, Beirut: Dar al-Fikr, 1988.

Dahlan, Abd. Rahman., Ushul Fiqh, Jakarta: Amzah, 2010.

Departemen Pendidikan Nasional, Kamus 
Besar Bahasa Indonesia, Jakarta: Pusat

Bahasa, 2008.

Hadikusuma, Hilman., Antropologi Hukum Indonesia, Bandung: Alumni, 1986.

-------, Hukum Kekerabatan Adat, Jakarta: Fajar Agung, 1987.

-------, Hukum Perkawinan Adat, Bandung:

PT. Citra Aditya Bakti, 1995.

Halim, Abdul., "Hazairin dan Pemikirannya tentang Pembaharuan Hukum

Kekeluargaan dalam Islam", Penelitian Jurnal Agama, No. 18, Th. VII, 1998.

Hamid, Abdul Ghoni., "Kewarisan dalam Perspektif Hazairin", Jurnal Studi Agama dan Masyarakat, Vol. 4, No. 1, Juni 2007.

Hamka, Sejarah Umat Islam Jilid II, Jakarta: Bulan Bintang, 1976.

Hazairin, Hukum Kewarisan Bilateral Menurut al-Qur'an dan Hadith, Jakarta: Tintamas, 1982 .

-------, Hukum Kekeluargaan Nasional, Jakarta: Tintamas, 1982.

Hidayat, Komaruddin., dan AF, Ahmad Gaus., [ed.], Islam Negara \& Civil Society; Gerakan dan Pemikiran Islam Kontemporer, Jakarta: Paramadina, 2005. Jones, Gavin W., "Agama-agama di Indonesia:

Sejarah dan Perkembangannya",

Prisma, No. 5, 1978.

Kharlie, Ahmad Tholabi., Hukum Keluarga Indonesia, Jakarta: Sinar Grafika, 2013.

Komnas Perempuan, "Dokumen Nasional:

Penerapan Hukum Keluarga Islam di Indnoesia", Hasil kesepakatan bersama dalam Konstultasi Nasional: Mencapai Hukum Keluarga yang Adil dan Setara Gender, Jakarta: Hotel Harris, 3-4 Februari 2009.

Kuntowijoyo, Dinamika Sejarah Umat Islam Indonesia, Yogyakarta: Salahuddin Press, 1984.
Makruf, Jamhari, dan Lindsey, Tim, (ed.)., Hukum Keluarga, Pidana \& Bisnis:

Kajian Perundang-undangan Indonesia, Fikih dan Hukum Internasional, Jakarta: Kencana, 2013.

Mansur, "Kontekstualisasi Gagasan Fiqh Indonesia T.M. Hasbi AshShiddieqy; Telaah atas Pemikiran Kritis Yudian Wahyudi", ASY-SYIR'AH Jurnal Ilmu Syari'ah dan Hukum, Vol. 46, No. 1, Januari-Juni 2012.

Mukri, Moh., "Dinamika Pemikiran Fikih Mazhab Indonesia: Perspektif Sejarah

Sosial”, Analisis, Vol. XI, No. 2, Desember 2011.

Nasution, Khoiruddin., "Arah Pembangunan Hukum Keluarga Islam Indonesia:

Pendekatan Integratif dan Interkonektif dalam Membangun Keluarga Sakinah", ASY-SYIR'AH Jurnal Ilmu Syari'ah dan Hukum, Vol. 46, No. 1, J a n u a r i - J u n i 2012.

-------, Hukum Perdata (Keluarga) Islam Indonesia dan Perbandingan Hukum

Perkawinan di Dunia Muslim: StudiSejarah, Metode Pembaharuan dan Materi \& Status Perempuan dalam Undang-undang Perkawinan Muslim, Yo g y a k r t a : ACAdeMIA+TAZZAFA, 2009.

-------, Pengantar dan Pemikiran Hukum Keluarga (Perdata) Islam Indonesia, Yogyakarta: ACAdeMIA+TAZZAFA, 2010.

Passen, Y. van., "Kerjasama Antar Agama dan Prospeknya: Kasus Sulawesi Utara", Prisma, No. 5, Edisi 1978.

Poesponegoro, Mawarti Djoned, dkk., Sejarah Nasional Indonesia Jilid III, Jakarta: Balai Pustaka Departemen Pendidikan dan Kebudayaan, 1984.

Ridha, As-Sayyid Muhammad Rasyid., Tafsir 
Al-Qur'an al-Hakim: Tafsir al- Ma n a r, Beirut: Dar al-Fikr, 1973.

Shiddieqy, Hasbi Ash., Syari'at Islam Menjawab Tantangan Zaman, Yogyakarta: I A I N Sunan Kalijaga, 1961.

Shihab, Muhammad Quraish., Tafsir AlMisbah, Jakarta: Lentera Hati, 2000.

Simorangkir dan Sastropranoto, Woerjono., Pelajaran Hukum Indonesia, Jakarta:

Gunung Agung, 1957.

Soewondo, Nani., Kedudukan Wanita Indonesia dalam Hukum dan Masyarakat, Jakarta: Timun Mas, 1968.

Sudiyat, Iman., Hukum Adat: Sketsa Asas, Yogyakarta: Liberty, 1981.

Summa, M. Amin., Hukum Keluarga Islam di Dunia Islam, Jakarta: RajaGrafindo Persada, 2004.

Tim Puspar UGM (Peny.)., Wawasan Budaya Untuk Pembangunan: Menoleh Kearifan Lokal, Yogyakarta: Pilar Politika, 2004.

Utrecht, Pengantar dalam Hukum Indonesia, Jakarta: Balai Buku Indonesia, 1953.

Wahyudi, Yudian K., Ushul Fikih versus Hermeneutika: Membaca Islam dari Kanada dan Amerika, Yogyakarta: Pesantren Nawesea Press, 2007.

-------, Hasbi's Theory of Ijtihad in the Context of Indonesian Fiqh, Yogyakarta: Pesantren Nawesea Press, 2007.

Wignjodipuro, Surojo., Pengantar dan Azasazas Hukum Adat, Bandung: Alumni, 1971.

Zuhaili, Wahbah., al-Fiqh al-Islami wa Adillatuhu, Penerjemah Abdul Hayyie alKattani dkk., Jakarta: Gema Insani, 2011. 
JURNAL AQLAM -- Journal of Islam and Plurality-- Volume 2, Nomor 1, Juni 2017 